\title{
Evaluation of protein biomarkers of prostate cancer aggressiveness
}

\author{
Anthony E Rizzardi ${ }^{1,2}$, Nikolaus K Rosener ${ }^{2}$, Joseph S Koopmeiners ${ }^{3,4}$, Rachel Isaksson Vogel ${ }^{3}$, Gregory J Metzger ${ }^{5}$, \\ Colleen L Forster ${ }^{6}$, Lauren O Marston², Jessica R Tiffany ${ }^{2}$, James B McCarthy ${ }^{2}$, Eva A Turley ${ }^{7,8}$, \\ Christopher A Warlick ${ }^{9}$, Jonathan C Henriksen ${ }^{1,2,6}$ and Stephen C Schmechel ${ }^{1,2,6^{*}}$
}

\begin{abstract}
Background: Prognostic multibiomarker signatures in prostate cancer (PCa) may improve patient management and provide a bridge for developing novel therapeutics and imaging methods. Our objective was to evaluate the association between expression of 33 candidate protein biomarkers and time to biochemical failure (BF) after prostatectomy.

Methods: PCa tissue microarrays were constructed representing 160 patients for whom clinicopathologic features and follow-up data after surgery were available. Immunohistochemistry for each of 33 proteins was quantified using automated digital pathology techniques. Relationships between clinicopathologic features, staining intensity, and time to BF were assessed. Predictive modeling using multiple imputed datasets was performed to identify the top biomarker candidates.

Results: In univariate analyses, lymph node positivity, surgical margin positivity, non-localized tumor, age at prostatectomy, and biomarkers CCND1, HMMR, IGF1, MKI67, SIAH2, and SMAD4 in malignant epithelium were significantly associated with time to BF. HMMR, IGF1, and SMAD4 remained significantly associated with BF after adjusting for clinicopathologic features while additional associations were observed for HOXC6 and MAP4K4 following adjustment. In multibiomarker predictive models, 3 proteins including HMMR, SIAH2, and SMAD4 were consistently represented among the top 2, 3, 4, and 5 most predictive biomarkers, and a signature comprised of these proteins best predicted BF at 3 and 5 years.
\end{abstract}

Conclusions: This study provides rationale for investigation of HMMR, HOXC6, IGF1, MAP4K4, SIAH2, and SMAD4 as biomarkers of PCa aggressiveness in larger cohorts.

Keywords: Prostate cancer, Aggressiveness, Biomarker, Signature

\section{Background}

Although prostate cancer ( $\mathrm{PCa}$ ) is the most commonly diagnosed non-cutaneous cancer of men in the United States [1], few prognostic biomarkers are available for routine clinical use. Serum PSA biochemical failure (BF) versus non-failure is a well-established binary outcome variable. Since clinical treatment failure (systemic progression and/or local recurrence) is essentially always preceded by BF (by a median of 8 years) [2-5], PSA non-

\footnotetext{
* Correspondence: sschmech@uw.edu

'Department of Pathology, University of Washington, Mailcode 359791, 908 Jefferson St, Seattle, WA 98104, USA

2Department of Laboratory Medicine and Pathology and Masonic Cancer Center, University of Minnesota, Minneapolis, MN, USA

Full list of author information is available at the end of the article
}

failure has high negative predictive value (NPV) for poor clinical outcome after prostatectomy. When identifying and validating new potential tissue based biomarkers for the purpose of attempting to improve prognostication after prostatectomy, the greatest clinical risk would be to mischaracterize biologically aggressive disease as "non-aggressive," since that would lead to erroneous underestimation of the malignant potential of the disease. For this reason, we seek tissue based biomarkers that maximally correlate with PSA failure.

Multibiomarker signatures and gene associations have been implicated in $\mathrm{PCa}$ progression but few markers emerge among multiple independent studies as potentially prognostic, outperform established clinicopathologic parameters in predicting $\mathrm{BF}$ following prostatectomy, or 
have become routinely used in clinical labs [6-18]. Current prognostic indicators in PCa include preoperative PSA, tumor stage, and grade [19]. Prognostic molecular biomarkers may identify pathways that can be exploited for therapy. For example, the TMPRSS2/ERG gene fusion was identified as a frequent chromosomal rearrangement present in a subgroup of prostate tumors that leads to ERG transcription factor overexpression [20]. Subsequent studies have demonstrated that inhibiting this pathway by delivery of liposomal nanovectors carrying siRNA specific for the TMPRSS2/ERG fusion transcript provides therapeutic advantage in a murine PCa model [21]. Additionally, multibiomarker signatures can be spatially quantified to aid in the development of novel imaging methods to assess PCa aggressiveness preoperatively in vivo through co-registration of postoperative pathology data with preoperative imaging data [22].

Numerous studies have described biomarkers of aggressive biologic behavior in PCa such as those correlated with aberrant hyaluronan (HA) processing $[8,11,12]$, neuroendocrine phenotype [14,23], increased tumor angiogenesis $[24]$, and poor prognosis [7,25]. Other groups have developed multi-biomarker signatures of PCa aggressiveness using gene expression profiling as a method for biomarker discovery; these studies have surprisingly little overlap between gene sets $[6,9,10,13,15-18]$. In this study, we took a combined approach of a) non-biased, cross-study examination of gene expression profiling data and b) a candidate gene approach (gene products that appear to be associated with PCa outcome in prior publications), to identify 33 potential aggressiveness biomarkers. We evaluated the association of these biomarkers with BF using immunohistochemistry and automated digital pathology techniques on tissue microarrays (TMAs) representing PCa tissue from 160 prostatectomy specimens.

\section{Methods}

\section{Selection of candidate proteins}

We identified 33 genes for study at the protein level by immunohistochemistry. Eleven genes were selected based on our own cross-study analysis of three publicly available PCa gene expression profiling datasets as described in Additional files 1, 2, 3, 4, 5, 6, 7, 8, 9, 10, 11, 12 (ACPP, ADAM9, ALDH1A2, CASR, CCPG1, GADD45B, HOXC6, IGF1, IQCK, PAGE4, PLIN2). Four genes were included based on their occurrence in multiple published gene signatures of PCa aggressiveness (CHMP1A, EI24, MAP4K4, MKI67) [6,9,16,17]. Additional candidates were included based on PCa literature review and included: 6 genes associated with HA processing in PCa (HA, HAS2, HMMR, HYAL1, CD44, CD44v6) [8,11,12]; 4 genes implicated in poor prognosis of PCa (CCND1, PTEN, SMAD4, SPP1) [7]; 3 genes characteristic of the neuroendocrine prostate tumor phenotype (CHGA, ENO2, SYP) [23]; 3 genes associated with development of neuroendocrine prostate tumors (HES6, SIAH2, SOX9) [14]; 1 marker of tumor angiogenesis (CD34) [24]; and 1 tumor suppressor gene associated with poor progression (TP53) [25].

\section{Clinical cohort and TMA construction}

Archival formalin-fixed paraffin-embedded tissues from patients with Gleason score 6, 7, 8, and 9 prostate acinar/ conventional adenocarcinomas that underwent radical prostatectomy at the University of Minnesota Medical Center Fairview from 1999 to 2008 were retrospectively collected after approval from the University of Minnesota Institutional Review Board. Patients with tumors predominantly containing Gleason pattern $5(5+4$ and $5+5$ morphology) were excluded. Our study focused on biomarker expression in tumor cells comprising primary Gleason patterns 3 and 4. Molecular evidence suggests that tumor of Gleason pattern 5 morphology is biologically distinct from tumor of Gleason patterns 3 and 4 $[26,27]$. Further, there is epidemiological evidence that Gleason pattern 4 represents a pattern intermediate between lower risk (pattern 3) and much higher risk (pattern 5) prostate cancer. For these reasons, we believe that tumor cells of pattern $3(3+3)$ and pattern $4(4+4$, and the pattern 4 component of $3+4,4+3$, and $4+5$ tumors) are of most interest in prognostic biomarker studies. Demographic and clinical parameters were abstracted from preexisting pathology reports and electronic medical records. Representative $\mathrm{PCa}$ areas were identified on hematoxylin and eosin-stained sections for each case. TMAs consisting of quadruplicate $1.0 \mathrm{~mm}$ core samples were constructed with a manual tissue arrayer (MTA-1, Beecher, Sun Prairie, WI).

\section{Immunohistochemistry}

Unstained, $4 \mu \mathrm{m}$-thick sections were deparaffinized and rehydrated using standard methods. Table 1 contains detailed information on sources, dilutions, antigen retrieval, and detection methods for each antibody. Antibodies were optimized with positive and negative control tissues and patterns of expression were demonstrated to be highly similar to those seen in previous publications (Additional file 13: Table S12). Most antibodies required standard antigen retrieval; slides were incubated in $6.0 \mathrm{pH}$ buffer (Reveal Decloaker; Biocare Medical, Concord, CA) in a steamer for $30 \mathrm{~min}$ at $95-98^{\circ} \mathrm{C}$, followed by a $20 \mathrm{~min}$ cool down period. Slides were rinsed in $1 \times$ Tris-buffered saline/0.1\% Tween-20 (TBST; pH 7.4). Subsequent steps were automated using a robotic staining platform (Nemesis; Biocare), except MKI67 and TP53 immunohistochemistry which were performed on a Ventana platform using the manufacturer's specifications (Ventana Medical Systems, Tucson, AZ). Endogenous peroxidase activity was quenched with $3 \%$ hydrogen peroxide 
Table 1 Antibodies and conditions used for immunohistochemistry assays

\begin{tabular}{|c|c|c|c|c|c|c|c|c|}
\hline Antibody & Specificity & Clone & Dilution & Antigen retrieval & Incubation & Detection & Source & Cat \# \\
\hline$\overline{\mathrm{ACPP}}$ & Polyclonal (rabbit) & - & $1: 2500$ & Steamer/Citrate pH 6 & $1 \mathrm{~h}$ & $\begin{array}{l}\text { Novocastra Novolink } \\
\text { Polymer }\end{array}$ & Sigma-Aldrich & HPA004335 \\
\hline ADAM9 & Polyclonal (rabbit) & - & $1: 100$ & Steamer/Citrate pH 6 & $1 \mathrm{~h}$ & $\begin{array}{l}\text { Novocastra Novolink } \\
\text { Polymer }\end{array}$ & Sigma-Aldrich & HPA004000 \\
\hline ALDH1A2 & Polyclonal (rabbit) & - & $1: 1000$ & Steamer/Citrate pH 6 & $1 \mathrm{~h}$ & $\begin{array}{l}\text { Novocastra Novolink } \\
\text { Polymer }\end{array}$ & Sigma-Aldrich & HPA010022 \\
\hline CASR & Polyclonal (rabbit) & - & $1: 200$ & Steamer/Citrate pH 6 & $1 \mathrm{~h}$ & $\begin{array}{l}\text { Novocastra Novolink } \\
\text { Polymer }\end{array}$ & Abcam & ab18200 \\
\hline CCND1 & Monoclonal (mouse) & DCS-6 & $1: 50$ & Decloaker/Citrate pH 6 & $1 \mathrm{~h}$ & $\begin{array}{l}\text { Novocastra Novolink } \\
\text { Polymer }\end{array}$ & Dako & M7155 \\
\hline CCPG1 & Polyclonal (rabbit) & - & $1: 400$ & Steamer/Citrate pH 6 & $1 \mathrm{~h}$ & $\begin{array}{l}\text { Novocastra Novolink } \\
\text { Polymer }\end{array}$ & Sigma-Aldrich & HPA026861 \\
\hline CD34 & Monoclonal (mouse) & QBEnd/10 & $1: 4000$ & Steamer/Citrate pH 6 & $1 \mathrm{~h}$ & $\begin{array}{l}\text { Novocastra Novolink } \\
\text { Polymer }\end{array}$ & Neomarkers & MS-363-P \\
\hline CD44 & Monoclonal (mouse) & SP37 & $1: 400$ & Steamer/Citrate pH 6 & $\mathrm{O} / \mathrm{N}$ & $\begin{array}{l}\text { Novocastra Novolink } \\
\text { Polymer }\end{array}$ & Dako & M708201-2 \\
\hline CD44v6 & Monoclonal (mouse) & $2 \mathrm{~F} 10$ & $1: 1000$ & Steamer/Citrate pH 6 & $1 \mathrm{~h}$ & $\begin{array}{l}\text { Novocastra Novolink } \\
\text { Polymer }\end{array}$ & R\&D Systems & BBA13 \\
\hline CHGA & Monoclonal (mouse) & LK2H10 + PHE5 & $1: 800$ & Steamer/Citrate pH 6 & $1 \mathrm{~h}$ & $\begin{array}{l}\text { Novocastra Novolink } \\
\text { Polymer }\end{array}$ & $\begin{array}{l}\text { Biocare } \\
\text { Medical }\end{array}$ & CM010B \\
\hline CHMP1A & Polyclonal (rabbit) & - & $1: 100$ & Steamer/Citrate pH 6 & $1 \mathrm{~h}$ & $\begin{array}{l}\text { Novocastra Novolink } \\
\text { Polymer }\end{array}$ & Sigma-Aldrich & HPA006776 \\
\hline El24 & Polyclonal (rabbit) & - & $1: 8000$ & Steamer/Citrate pH 6 & $1 \mathrm{~h}$ & $\begin{array}{l}\text { Novocastra Novolink } \\
\text { Polymer }\end{array}$ & Sigma-Aldrich & SAB1100756 \\
\hline ENO2 & Monoclonal (mouse) & $5 \mathrm{E} 2$ & $1: 800$ & No AR & $1 \mathrm{~h}$ & $\begin{array}{l}\text { Novocastra Novolink } \\
\text { Polymer }\end{array}$ & Leica & NCL-L-NSE2 \\
\hline GADD45B & Polyclonal (rabbit) & - & $1: 25$ & Steamer/Citrate pH 6 & $1 \mathrm{~h}$ & $\begin{array}{l}\text { Novocastra Novolink } \\
\text { Polymer }\end{array}$ & Sigma-Aldrich & HPA029816 \\
\hline $\mathrm{HABP} \mathrm{P}^{\mathrm{a}}$ & NA (bovine) & - & $1: 400$ & No AR & $\mathrm{O} / \mathrm{N}$ & VECTASTAIN Elite $A B C^{b}$ & Calbiochem & 385911 \\
\hline HAS2 & Polyclonal (goat) & - & $1: 1000$ & Steamer/Citrate pH 6 & $1 \mathrm{~h}$ & VECTASTAIN Elite ABC & Santa Cruz & sc-34067 \\
\hline HES6 & Polyclonal (rabbit) & - & $1: 1000$ & Steamer/Citrate pH 6 & $\mathrm{O} / \mathrm{N}$ & $\begin{array}{l}\text { Novocastra Novolink } \\
\text { Polymer }\end{array}$ & Abcam & $a b 66461$ \\
\hline HMMR & Monoclonal (mouse) & 6B7D8 & $1: 900$ & Steamer/Citrate pH 6 & $1 \mathrm{~h}$ & $\begin{array}{l}\text { Covance Ultra } \\
\text { Streptavidin-HRP }\end{array}$ & ProMab & NA \\
\hline HOXC6 & Polyclonal (rabbit) & - & $1: 200$ & Steamer/Citrate pH 6 & $1 \mathrm{~h}$ & $\begin{array}{l}\text { Novocastra Novolink } \\
\text { Polymer }\end{array}$ & Santa Cruz & sc-66925 \\
\hline HYAL1 & Polyclonal (rabbit) & - & $1: 100$ & Steamer/Citrate pH 6 & $\mathrm{O} / \mathrm{N}$ & $\begin{array}{l}\text { Novocastra Novolink } \\
\text { Polymer }\end{array}$ & Sigma-Aldrich & HPA002112 \\
\hline IGF1 & Polyclonal (rabbit) & - & $1: 400$ & Steamer/Citrate pH 6 & $1 \mathrm{~h}$ & $\begin{array}{l}\text { Novocastra Novolink } \\
\text { Polymer }\end{array}$ & Millipore & 07-1411 \\
\hline IQCK & Polyclonal (rabbit) & - & $1: 70$ & Steamer/Citrate pH 6 & $1 \mathrm{~h}$ & $\begin{array}{l}\text { Novocastra Novolink } \\
\text { Polymer }\end{array}$ & Sigma-Aldrich & HPA026792 \\
\hline MAP4K4 & Polyclonal (rabbit) & - & $1: 100$ & Steamer/Citrate pH 6 & $1 \mathrm{~h}$ & $\begin{array}{l}\text { Novocastra Novolink } \\
\text { Polymer }\end{array}$ & Sigma-Aldrich & HPA008476 \\
\hline MKI67 & Monoclonal (mouse) & MM1 & Predilute & Decloaker/CCS1 & $32 \mathrm{~min}$ & $\begin{array}{l}\text { Ventana ultraView } \\
\text { Universal }\end{array}$ & Leica & ORG-8772 \\
\hline PAGE4 & Polyclonal (rabbit) & - & $1: 2000$ & Steamer/Citrate pH 6 & $1 \mathrm{~h}$ & $\begin{array}{l}\text { Novocastra Novolink } \\
\text { Polymer }\end{array}$ & Sigma-Aldrich & HPA023880 \\
\hline PLIN2 & Polyclonal (rabbit) & - & $1: 100$ & Steamer/Citrate pH 6 & $1 \mathrm{~h}$ & $\begin{array}{l}\text { Novocastra Novolink } \\
\text { Polymer }\end{array}$ & Abbiotec & 251533 \\
\hline PTEN & Polyclonal (rabbit) & - & $1: 200$ & Steamer/Citrate pH 6 & $1 \mathrm{~h}$ & $\begin{array}{l}\text { Novocastra Novolink } \\
\text { Polymer }\end{array}$ & Invitrogen & $18-0256$ \\
\hline $\mathrm{SIAH} 2$ & Monoclonal (mouse) & 24E6H3 & 1:50 & Steamer/Citrate pH 6 & $1 \mathrm{~h}$ & & Novus & NB1 10-88113 \\
\hline
\end{tabular}


Table 1 Antibodies and conditions used for immunohistochemistry assays (Continued)

\begin{tabular}{|c|c|c|c|c|c|c|c|c|}
\hline & & & & & & $\begin{array}{l}\text { Novocastra Novolink } \\
\text { Polymer }\end{array}$ & & \\
\hline SMAD4 & Monoclonal (rabbit) & EP618Y & $1: 100$ & Steamer/Citrate pH 6 & $1 \mathrm{~h}$ & $\begin{array}{l}\text { Novocastra Novolink } \\
\text { Polymer }\end{array}$ & Millipore & 04-1033 \\
\hline sox9 & Polyclonal (rabbit) & - & $1: 200$ & Steamer/Citrate pH 6 & $1 \mathrm{~h}$ & $\begin{array}{l}\text { Novocastra Novolink } \\
\text { Polymer }\end{array}$ & Sigma-Aldrich & HPA001758 \\
\hline SPP1 & Monoclonal (rabbit) & EPR3688 & $1: 50$ & Steamer/Citrate pH 6 & $1 \mathrm{~h}$ & $\begin{array}{l}\text { Novocastra Novolink } \\
\text { Polymer }\end{array}$ & Epitomics & $2671-1$ \\
\hline SYP & Monoclonal (mouse) & 27G12 & $1: 400$ & Steamer/Citrate pH 6 & $1 \mathrm{~h}$ & $\begin{array}{l}\text { Novocastra Novolink } \\
\text { Polymer }\end{array}$ & Leica & NCL-SYNAP-299 \\
\hline \multirow[t]{2}{*}{ TP53 } & Monoclonal (mouse) & DO-7 & $1: 40000$ & Steamer/Citrate pH 6 & $1 \mathrm{~h}$ & $\begin{array}{l}\text { Novocastra Novolink } \\
\text { Polymer }\end{array}$ & Dako & M7001 \\
\hline & Monoclonal (mouse) & Bp53-11 & Predilute & Decloaker/CCS1 & $16 \min$ & $\begin{array}{l}\text { Ventana ultraView } \\
\text { Universal }\end{array}$ & Ventana & $760-2542$ \\
\hline
\end{tabular}

CCS1, Cell conditioning solution 1 (Ventana).

aiotinylated conjugate.

${ }^{\mathrm{b}}$ Tertiary reagent only.

solution (Peroxidazed; Biocare) for $10 \mathrm{~min}$ followed by rinsing. Serum-free blocking solution (Background Sniper; Biocare) was applied for $10 \mathrm{~min}$. Blocking solution was removed and slides were incubated with primary antibody diluted in $10 \%$ blocking solution/90\% TBST. Primary antibody incubations were performed according to Table 1. Most detection was performed with the Novocastra Novolink Polymer Kit (Leica Microsystems, Buffalo Grove, IL). Detection for HAS2 was performed with the VECTASTAIN Elite ABC Kit (Vector, Burlingame, CA). Histochemical detection of HA was performed using biotinylated HA binding protein (bHABP) and only required the tertiary reagent of the VECTASTAIN Elite ABC Kit (Vector). To demonstrate specificity for bHABP, additional sections were pre-treated in $0.1 \mathrm{M}$ sodium acetate buffer ( $\mathrm{pH} 5.0$ )/1\% hyaluronidase (Sigma) for $45 \mathrm{~min}$ at $37^{\circ} \mathrm{C}$ (data not shown). Detection for HMMR was performed with a streptavidin-horseradish peroxidase (HRP) kit (Covance, Princeton, NJ). Final detection steps were completed using 3,3-diaminobenzidine (DAB; Covance). Slides were incubated for $5 \mathrm{~min}$ followed by rinsing, counterstaining (CAT Hematoxylin; Biocare), dehydrating, and coverslipping. A second independent run of immunohistochemistry and image analysis was performed for a subset of biomarkers to examine reproducibility.

\section{Slide digitization, annotation, and immunohistochemical quantification}

TMA slides were scanned at $40 \times$ magnification $\left(0.0625 \mu \mathrm{m}^{2} /\right.$ pixel) using a whole slide scanner (ScanScope CS or ScanScope XL; Aperio ePathology, Leica Biosystems, Vista, CA) and preprocessed using the Genie Histology Pattern Recognition software suite (Aperio) to segment tissues into three user-defined Image Classes (tumor, stroma, glass) as previously reported [28]. For markers with predominantly nuclear localization (CCND1, MKI67, SIAH2, and TP53), nuclear DAB staining was quantified within malignant epithelium using the Nuclear algorithm (Aperio). For the microvascular marker (CD34), DAB staining was quantified within whole tumor areas using the Color Deconvolution algorithm (Aperio) for standard area quantification as well as the Microvessel algorithm (Aperio) for quantification of alternative metrics that may be prognostic (average vessel area, average vessel perimeter, average lumen area, average vascular area, and microvessel density). For the remaining markers, $D A B$ staining was quantified within malignant epithelium using the Color Deconvolution algorithm (Aperio), except for HA quantified in tumor-associated stroma and EI24 quantified in both tumor-associated stroma and malignant epithelium (individually). Data obtained using standard Color Deconvolution (Aperio) were summarized by a continuous variable metric that incorporates both the staining strength (measured as average optical density $[\mathrm{OD}]$ units since $\mathrm{OD}$ is linearly related to amount of DAB staining [29]) and the percentage of positive pixels in malignant epithelium or tumor-associated stromal areas (AvgOD*\%Pos). This metric accounts for differences in staining intensities as well as the proportion of positive staining tumor and was previously found to be highly correlated with visual pathologist scoring [28]. Similarly, data obtained using the Nuclear algorithm (Aperio) were summarized as the average staining intensity within nuclei of malignant epithelium (AvgNuclearOD) multiplied by the percentage of positive nuclei in malignant epithelium (AvgNuclearOD*\% PosNuclei).

\section{Statistical analysis}

The primary statistical analysis focused on the association between biomarkers and BF. Time to BF was 
calculated from date of prostatectomy to the date of known $\mathrm{BF}$, defined as the date of a PSA value $\geq 0.2 \mathrm{ng} / \mathrm{mL}$ (taken at least 6 weeks after surgery) and confirmed by a second PSA value $>0.2 \mathrm{ng} / \mathrm{mL}$ [2]. Time to $\mathrm{BF}$ was censored at the last date of contact for subjects who did not experience BF. Patients with only a single post-operative PSA value were excluded. Clinicopathologic features used for statistical analysis included pre-operative PSA (continuous), age at prostatectomy (continuous), primary Gleason pattern (3: $3+3$ and $3+4$; or $4: 4+3,4+4$, and $4+5$ ), and NonLocalized Tumor Indicator (yes or no) which was defined by tumor that extended beyond the prostate (pathologic stage pT3), involved lymph nodes (pN1), and/or had positive surgical margin (s) (pR1). Clinicopathologic features and biomarker staining data (averaged across spots by biomarker for each patient) were evaluated for their association with $\mathrm{BF}$ using Cox proportional hazards regression. Associations were summarized with the hazard ratio (HR) (per 1 standard deviation difference in biomarker measurement) and $95 \%$ confidence interval. P-values of $\leq 0.05$ were considered statistically significant.

In addition, we developed a multibiomarker predictive model for time to BF using a subset of the biomarkers considered in our primary analysis. In order to account for missing biomarker values, ten imputed datasets were generated by chained equations [30] using the 'mice' package in $\mathrm{R}$ [31]. For each imputed dataset, predictive models were developed for time to BF using the best 2 , 3 , 4, and 5 biomarkers with variable selection completed using the Lasso [32]. Data were summarized by counting the number of times each biomarker appeared in the top 2, 3, 4 and 5 biomarkers across the ten imputed datasets. From this list, we identified the top 3 biomarkers. The classification accuracy of our multibiomarker predictive model was estimated by calculating the area under the survival ROC curve (AUC) [33] for each imputed dataset and averaging the estimates over the ten imputed datasets. A cross-validation procedure was used to adjust for overfitting and $95 \%$ confidence intervals were completed using the bootstrap.

\section{Results}

\section{Immunohistochemical analysis of PCa related proteins}

A select group of 33 proteins implicated in advanced PCa or disease progression was evaluated by immunohistochemistry (Table 1) on our PCa cohort TMAs. Immunohistochemical staining patterns were verified using normal and tumor control tissues (described in Additional file 13: Table S12; representative tissues shown in Additional file 14: Figure S1). PCa tissues exhibited positive staining for each of the 33 proteins as illustrated in Figure 1. The image analysis workflow for immunohistochemical staining quantification is displayed in Figure 2.
Additional studies were performed on 8 of the 33 biomarkers (24\%) (CCND1, CD44s, CD44v6, HA, HAS2, HMMR, HYAL1, and SMAD4) to investigate the reproducibility of IHC and image analysis. The number of cases with available data varied for each biomarker due to tissue core loss (technical reasons) or exclusion (quality control). For each of the biomarkers, $71.2-84.7 \%$ of subjects had evaluable IHC staining on tissue samples for both runs, $0.6-11.8 \%$ were missing tissue for one of the two runs, and $8.8-11.8 \%$ were missing tissue for both runs (Additional file 15: Table S13). These data losses are within the expected missing data range of $6-30 \%$ for TMA-based methodologies [34]. The correlation coefficient for subjects with two independent evaluable marker values ranged from 0.54-0.81 (Additional file 15: Table S13).

\section{Clinicopathologic features of PCa patients and BF}

A total of 160 subjects met our eligibility criteria and had suitable tissue available for analysis for at least one biomarker. The mean age at the time of prostatectomy was 60.8 years and the average pre-operative PSA was $7.2 \mathrm{ng} / \mathrm{mL}$. A Kaplan-Meier curve for time to BF can be found in Figure 3. Out of 160 patients, 22 experienced BF during follow-up with a median time to BF of 9.6 years (95\% CI: 6.9-Inf). The median follow-up among nonfailures was 2.3 years (range 50-3156 days). Tumor characteristics are summarized in Table 2. Combined Gleason score, pathologic stage, lymph node involvement, surgical margin involvement, Non-Localized Tumor Indicator, and increased age at prostatectomy were significantly associated with time to BF (Table 2). Preoperative PSA and primary Gleason pattern were not found to be statistically significant; however, multivariate analyses were adjusted for all clinicopathologic features including preoperative PSA and primary Gleason pattern based on established prognostic factors for BF [19].

\section{Prognostic significance of proteins implicated in aggressive prostate cancer}

Malignant epithelial staining of CCND1 (nuclear; $\mathrm{p}=0.042$ ), HMMR ( $p=0.005)$, IGF1 $(p=0.039)$, MKI67 (nuclear; $p=$ 0.026), SIAH2 (nuclear; $\mathrm{p}=0.016)$, and SMAD4 $(\mathrm{p}=0.010)$ were significantly associated with time to BF before adjusting for clinicopathologic features (Table 3). After adjustment for clinicopathologic features, HMMR $(\mathrm{p}=0.008)$, IGF1 $(\mathrm{p}=0.015)$, SMAD4 $(\mathrm{p}=0.016)$ remained significantly associated and new associations were observed for HOXC6 $(\mathrm{p}=0.050)$ and MAP4K4 $(\mathrm{p}=0.024)$. These data demonstrate that HMMR, HOXC6, IGF1, MAP4K4, and SMAD4 are associated with time to BF and that their associations are not fully explained by currently established clinicopathologic parameters. 


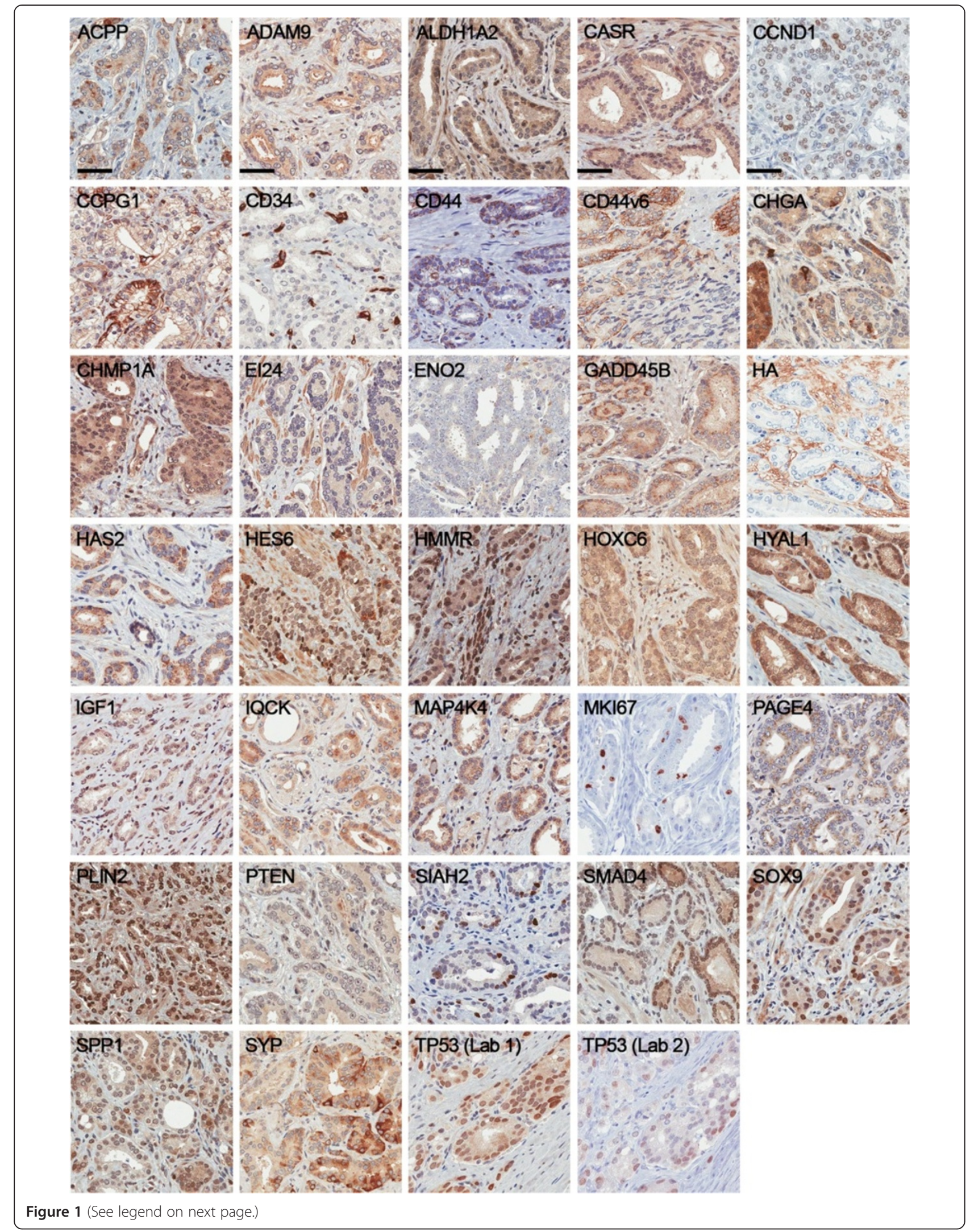


(See figure on previous page.)

Figure 1 Immunohistochemistry of candidate biomarkers in prostate cancer. Representative immunohistochemical staining of $A C P P$, ADAM9, ALDH1A2, CASR, CCND1, CCPG1, CD34, CD44, CD44v6, CHGA, CHMP1A, El24, ENO2, GADD45B, HA, HAS2, HES6, HMMR, HOXC6, HYAL1, IGF1, IQCK, MAP4K4, MKI67, PAGE4, PLIN2, PTEN, SIAH2, SMAD4, SOX9, SPP1, SYP, and TP53 from prostate cancer tissue microarrays. Scale bar represents $50 \mu \mathrm{m}$.

\section{Multiple imputations and multibiomarker modeling of prostate cancer aggressiveness}

Table 4 presents the frequency with which each biomarker appeared in the top 2, 3, 4 and 5 biomarkers across the ten imputed datasets. Three proteins (HMMR, SIAH2, and SMAD4) were consistently present in the top $2,3,4$, and 5 most predictive biomarkers $(4,10$, and 7 times in the top 3 , respectively). A predictive model comprised of HMMR, SIAH2, and SMAD4 had an AUC of 0.69 (95\% CI: $0.50,0.78)$ for BF at 3 years and $0.70(95 \%$ CI: $0.53,0.87)$ for BF at 5 years (Table 5 ).

\section{Discussion}

While established clinicopathologic features including grade, stage, and preoperative PSA partially explain the variability in $\mathrm{PCa}$ outcome measured by $\mathrm{BF}$ after prostatectomy, further stratification of patients for more precise patient management may be possible with prognostic multibiomarker signatures. Many signatures and gene associations of PCa progression have been identified [6-18,23-25], but few markers emerge among multiple independent studies as potentially prognostic, outperform established clinicopathologic features, or become widely used. Identification of robust prognostic biomarkers will not only improve the clinical management of $\mathrm{PCa}$, but is expected to provide an important bridge between pathology data and imaging data to facilitate development of novel imaging biomarkers which can be assessed noninvasively [22]. The present study focused on evaluating the prognostic utility of 33 proteins and investigating multibiomarker signatures that were predictive of BF. Although these proteins have been previously implicated in aggressive biologic behavior of $\mathrm{PCa}$ from diverse

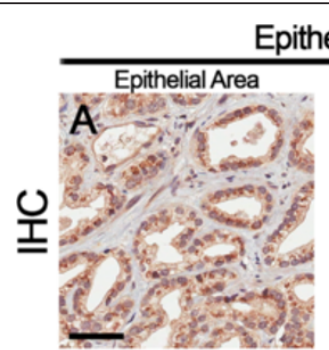

\section{Epithelium}
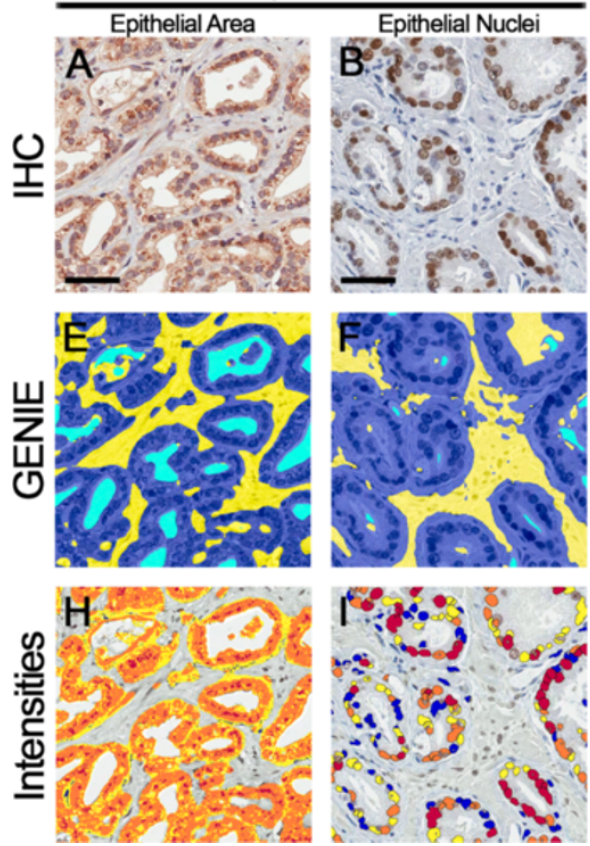
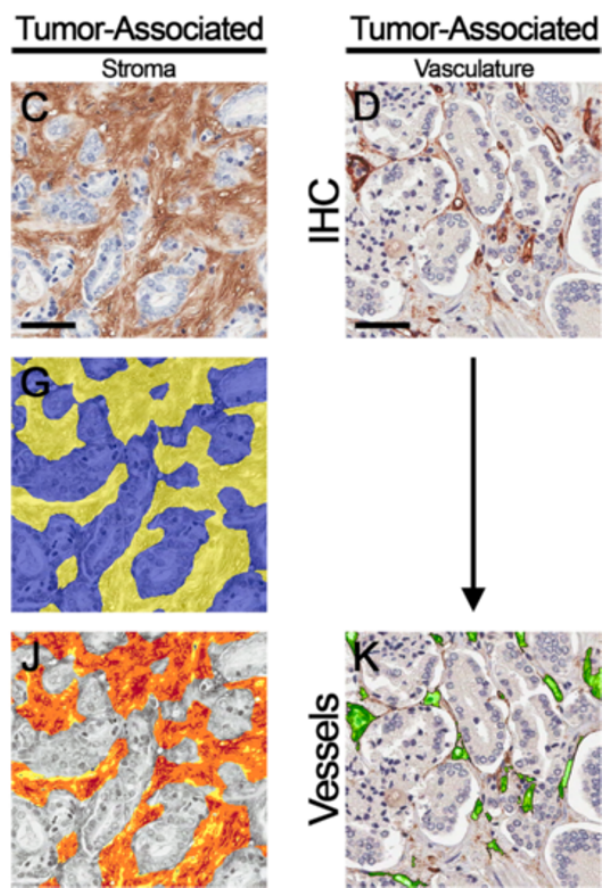

Figure 2 Image analysis workflow for immunohistochemical staining quantification. (A-D) Prostate cancer tissue microarrays were stained by immunohistochemistry. The method of image analysis performed independently for each marker was dependent on the staining pattern: default malignant epithelial area (A), malignant epithelial nuclei (B), tumor-associated stromal area (C), or tumor-associated vasculature (D). (E-G) Genie Histology Pattern Recognition software (Aperio) subclassified tumor areas into malignant epithelium (dark blue), stroma (yellow), and glass (light blue). (H) Markers with heterogeneous positivity were evaluated by Color Deconvolution (Aperio) to quantify staining within malignant epithelial areas. (I) Markers with predominantly nuclear localization (CCND1, MKI67, SIAH2, and TP53) were evaluated by the Nuclear algorithm (Aperio) to quantify staining within nuclei of malignant epithelium. (J) Markers with significant stromal positivity (EI24 and HA) were evaluated by Color Deconvolution (Aperio) to quantify staining within tumor-associated stroma. (K) The microvascular marker (CD34) was evaluated by the Microvessel algorithm (Aperio) to quantify additional metrics including average vessel area, average vessel perimeter, average lumen area, average vascular area, and microvessel density. Scale bars represent $50 \mu \mathrm{m}$. 


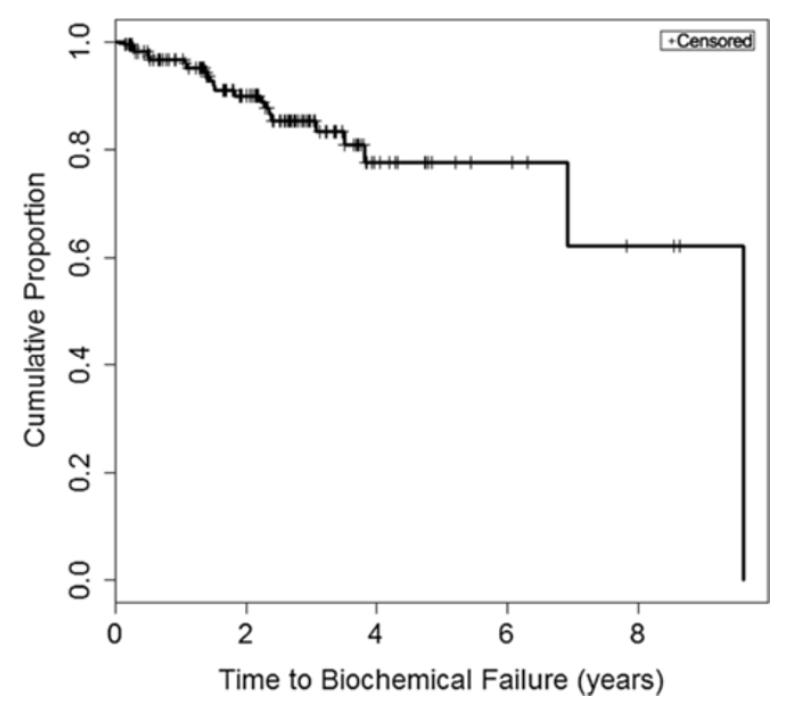

Figure 3 Kaplan-Meier curve demonstrating the time to biochemical failure for the sample population.

studies, to our knowledge this is the first study to examine these proteins in a single prostatectomy cohort using immunohistochemistry and objective automated digital pathology methods. We found that increased levels of several proteins in malignant epithelium were significantly associated with time to BF after adjustment for established clinicopathologic parameters including HMMR, HOXC6, IGF1, MAP4K4, and SMAD4. We also demonstrated that a 3-biomarker signature including HMMR, SMAD4, and SIAH2 was predictive of $\mathrm{BF}$ in our cohort, warranting further investigation of this signature in larger cohorts and imaging biomarker development studies.

HMMR is a multicompartmentalized receptor for the extracellular matrix carbohydrate HA with potentially oncogenic functions such as mediating cell motility and affecting mitotic spindle integrity [35]. Aberrant HA pathway signaling is implicated in prostate tumor cell proliferation, motility, angiogenesis, and metastasis [36]. Our results indicated that elevated HMMR in malignant epithelium was associated with BF which is similar to previous reports linking HMMR expression to the development of castration-resistant PCa and metastatic disease $[12,37]$. Further, low molecular weight HA fragments are catabolized from native HA by physical (reactive oxygen/ nitrogen species) and enzymatic (hyaluronidase) mechanisms [38] and bind to HMMR to induce cell migration $[39,40]$. These data support the underlying model of aberrant HA-HMMR signaling in aggressive PCa and are encouraging for ongoing studies in our laboratories using small molecular inhibitors to disrupt fragmented HAHMMR interactions for therapeutic targeting.

HOXC6 was identified in our cross-study analysis of gene expression datasets as part of an 11-gene signature
Table 2 Association of clinicopathologic features with time to biochemical failure using univariate Cox regression models

\begin{tabular}{|c|c|c|c|c|}
\hline Variable & $\mathrm{N}$ & $\%$ & HR $(95 \% \mathrm{Cl})$ & P-value \\
\hline Total population & 160 & & & \\
\hline Combined Gleason score & & & & 0.034 \\
\hline $3+3$ & 50 & 31.3 & $0.09(0.02-0.51)$ & \\
\hline $3+4$ & 63 & 39.4 & $0.17(0.03-0.78)$ & \\
\hline $4+3$ & 34 & 21.3 & $0.17(0.03-0.92)$ & \\
\hline $4+4$ & 8 & 5.0 & $0.11(0.01-1.23)$ & \\
\hline $4+5$ & 5 & 3.1 & 1.00 & \\
\hline Primary Gleason pattern & & & & 0.347 \\
\hline 3 & 113 & 70.6 & $0.65(0.27-1.58)$ & \\
\hline 4 & 47 & 29.4 & 1.00 & \\
\hline Pathologic stage & & & & 0.013 \\
\hline $\begin{array}{l}\text { Extraprostatic extension } \\
\text { (pT3+) }\end{array}$ & 29 & 18.1 & $3.13(1.28-7.69)$ & \\
\hline Prostate-limited (pT2) & 131 & 81.9 & 1.00 & \\
\hline $\begin{array}{l}\text { Lymph node } \\
\text { involvement }\end{array}$ & & & & 0.018 \\
\hline Yes (pN1) & 5 & 3.1 & $4.46(1.29-15.37)$ & \\
\hline No $(p N 0)$ & 155 & 96.9 & 1.00 & \\
\hline Surgical margin & & & & 0.022 \\
\hline \multicolumn{5}{|l|}{ involvement } \\
\hline Yes (pR1) & 53 & 33.1 & $2.82(1.17-6.84)$ & \\
\hline No (pRo) & 107 & 66.9 & 1.00 & \\
\hline $\begin{array}{l}\text { Non-Localized } \\
\text { tumor Indicator* }\end{array}$ & & & & 0.005 \\
\hline Yes & 67 & 41.9 & $4.21(1.54-11.50)$ & \\
\hline \multirow[t]{2}{*}{ No } & 93 & 58.1 & 1.00 & \\
\hline & $\mathbf{N}$ & Mean (SD) & HR (95\% Cl) & P-value \\
\hline Age (years) & 160 & $60.8(6.8)$ & $1.08(1.01-1.16)$ & 0.035 \\
\hline Pre-operative PSA (ng/mL) & 148 & $7.2(5.3)$ & $1.03(0.98-1.09)$ & 0.238 \\
\hline
\end{tabular}

*Non-Localized Tumor Indicator is a summary metric of tumor confined to prostate. 'Yes' indicates tumor growth beyond the prostate (pathologic stage $\mathrm{pT3}$ ), involved lymph nodes ( $\mathrm{pN} 1)$, and/or positive surgical margins (pR1).

of PCa aggressiveness. We further demonstrated an association between HOXC6 immunohistochemistry with time to BF in our PCa cohort. Similarly, Singh et al. identified HOXC6 in a 5-gene signature that was predictive of BF [15]. HOXC6 is an androgen-regulated gene which assists during development of normal tissues and progression of PCa [41]. Mouse models provide specific evidence for the interaction of HOXC6 with multiple downstream targets including bone morphogenic protein 7 (BMP7), fibroblast growth factor receptor 2 (FGFR2), and platelet-derived growth factor receptor $\alpha$ (PDGFRA) that promote PCa metastasis to the bone microenvironment [42]. Anti-apoptotic roles for HOXC6 have also been described in head and neck squamous 
Table 3 Biomarkers as predictors of time to biochemical failure using Cox regression models

\begin{tabular}{|c|c|c|c|c|c|}
\hline \multirow[b]{2}{*}{ Variable } & \multirow[t]{2}{*}{$\mathbf{N}$} & \multicolumn{2}{|c|}{ Univariate } & \multicolumn{2}{|c|}{ Multivariate* } \\
\hline & & HR $(95 \% \mathrm{Cl})$ & P-value & $\mathrm{HR}(95 \% \mathrm{Cl})$ & P-value \\
\hline ACPP & 139 & $0.93(0.63-1.39)$ & 0.735 & 1.07 (0.59-1.93) & 0.827 \\
\hline ADAM9 & 152 & $0.98(0.63-1.54)$ & 0.944 & $1.19(0.75-1.91)$ & 0.462 \\
\hline ALDH1A2 & 141 & $0.79(0.47-1.32)$ & 0.368 & $1.10(0.62-1.95)$ & 0.737 \\
\hline CASR & 143 & $1.01(0.65-1.57)$ & 0.949 & $0.98(0.58-1.66)$ & 0.937 \\
\hline CCND1 (nuclear) & 142 & $1.38(1.01-1.88)$ & 0.042 & $1.18(0.87-1.61)$ & 0.296 \\
\hline CCPG1 & 143 & $1.19(0.76-1.88)$ & 0.446 & $1.14(0.69-1.86)$ & 0.611 \\
\hline CD34 (avg vess area) & 146 & $1.16(0.74-1.83)$ & 0.515 & $1.02(0.60-1.74)$ & 0.938 \\
\hline CD34 (avg vess per) & 146 & $1.42(0.91-2.21)$ & 0.123 & $1.43(0.84-2.43)$ & 0.188 \\
\hline CD34 (avg lum area) & 146 & $1.45(0.95-2.22)$ & 0.086 & $1.37(0.83-2.27)$ & 0.220 \\
\hline CD34 (avg vasc area) & 146 & $1.02(0.66-1.60)$ & 0.915 & $0.89(0.52-1.53)$ & 0.682 \\
\hline CD34 (MVD) & 146 & $1.11(0.71-1.73)$ & 0.652 & $0.97(0.56-1.67)$ & 0.901 \\
\hline CD34 & 146 & $1.11(0.72-1.71)$ & 0.648 & $1.04(0.63-1.71)$ & 0.881 \\
\hline CD44 & 148 & $1.07(0.68-1.68)$ & 0.764 & $1.06(0.70-1.60)$ & 0.786 \\
\hline CD44v6 & 143 & $1.23(0.79-1.89)$ & 0.360 & $1.35(0.84-2.16)$ & 0.217 \\
\hline $\mathrm{CHGA}$ & 136 & $0.50(0.24-1.04)$ & 0.064 & $0.56(0.26-1.21)$ & 0.139 \\
\hline CHMP1A & 146 & $1.31(0.83-2.08)$ & 0.244 & $1.35(0.84-2.20)$ & 0.218 \\
\hline El24 (stroma) & 140 & $1.24(0.85-1.82)$ & 0.265 & $1.36(0.97-1.91)$ & 0.077 \\
\hline El24 (tumor) & 140 & $1.32(0.94-1.87)$ & 0.114 & $1.32(0.97-1.79)$ & 0.077 \\
\hline ENO2 & 145 & $1.33(0.92-1.93)$ & 0.135 & $1.48(0.92-2.38)$ & 0.108 \\
\hline GADD45B & 148 & $1.11(0.72-1.73)$ & 0.630 & $1.18(0.78-1.77)$ & 0.435 \\
\hline HA (stroma) & 150 & $1.51(0.99-2.29)$ & 0.055 & $1.43(0.95-2.17)$ & 0.090 \\
\hline HAS2 & 148 & $1.27(0.82-1.97)$ & 0.287 & $1.47(0.94-2.30)$ & 0.090 \\
\hline HES6 & 140 & $0.80(0.48-1.34)$ & 0.401 & $0.69(0.38-1.27)$ & 0.238 \\
\hline HMMR & 139 & $2.01(1.23-3.30)$ & 0.005 & $1.98(1.20-3.29)$ & 0.008 \\
\hline HOXC6 & 142 & $1.22(0.79-1.89)$ & 0.368 & $1.51(1.00-2.28)$ & 0.050 \\
\hline HYAL1 & 147 & $1.42(0.92-2.21)$ & 0.116 & $1.40(0.87-2.25)$ & 0.163 \\
\hline IGF1 & 147 & $1.57(1.02-2.42)$ & 0.039 & $1.67(1.10-2.52)$ & 0.015 \\
\hline IQCK & 149 & $0.90(0.58-1.40)$ & 0.651 & $0.90(0.59-1.38)$ & 0.625 \\
\hline MAP4K4 & 145 & $1.44(0.91-2.28)$ & 0.121 & $1.76(1.08-2.86)$ & 0.024 \\
\hline MKI67 (nuclear) & 142 & $1.43(1.04-1.96)$ & 0.026 & $1.29(0.93-1.79)$ & 0.125 \\
\hline PAGE4 & 145 & $0.68(0.45-1.03)$ & 0.069 & $0.88(0.57-1.35)$ & 0.566 \\
\hline PLIN2 & 115 & $1.21(0.71-2.09)$ & 0.481 & $1.07(0.62-1.86)$ & 0.801 \\
\hline PTEN & 144 & $0.83(0.54-1.27)$ & 0.393 & $0.84(0.51-1.38)$ & 0.493 \\
\hline SIAH2 (nuclear) & 144 & 1.46 (1.07-1.99) & 0.016 & $1.37(0.94-2.02)$ & 0.104 \\
\hline SMAD4 & 130 & $1.76(1.15-2.71)$ & 0.010 & $1.73(1.11-2.70)$ & 0.016 \\
\hline Sox9 & 145 & $1.39(0.90-2.16)$ & 0.137 & $1.45(0.93-2.27)$ & 0.101 \\
\hline SPP1 & 128 & $1.07(0.62-1.84)$ & 0.805 & $0.76(0.44-1.33)$ & 0.338 \\
\hline SYP & 133 & $0.88(0.48-1.63)$ & 0.681 & $0.95(0.53-1.70)$ & 0.869 \\
\hline TP53_Lab1 (nuclear) & 148 & $1.23(0.83-1.83)$ & 0.305 & $1.19(0.78-1.82)$ & 0.431 \\
\hline TP53_Lab2 (nuclear) & 143 & $0.97(0.63-1.50)$ & 0.906 & $0.93(0.60-1.44)$ & 0.741 \\
\hline
\end{tabular}

MVD, microvessel density.

*Adjusted for age at prostatectomy, pre-op PSA, primary Gleason pattern, and Non-Localized Tumor Indicator. 
Table 4 Frequency of biomarkers appearing in the top 2, 3,4 , and 5 biomarkers with highest area under the ROC curve (AUC) across 10 imputed datasets

\begin{tabular}{|c|c|c|c|c|}
\hline Variable & Top 2 & Top 3 & Top 4 & Top 5 \\
\hline ACPP & 0 & 0 & 0 & 0 \\
\hline ADAM9 & 0 & 0 & 0 & 0 \\
\hline ALDH1A2 & 0 & 0 & 0 & 0 \\
\hline CASR & 0 & 0 & 0 & 0 \\
\hline CCND1 (nuclear) & 0 & 0 & 0 & 0 \\
\hline CCPG1 & 0 & 0 & 0 & 0 \\
\hline CD34 (avg vess area) & 0 & 0 & 0 & 0 \\
\hline CD34 (avg vess per) & 0 & 1 & 4 & 5 \\
\hline CD34 (avg lum area) & 0 & 1 & 3 & 3 \\
\hline CD34 (avg vasc area) & 0 & 0 & 0 & 0 \\
\hline CD34 (MVD) & 0 & 0 & 0 & 0 \\
\hline CD34 & 0 & 0 & 0 & 0 \\
\hline CD44 & 0 & 0 & 0 & 0 \\
\hline CD44v6 & 0 & 2 & 2 & 2 \\
\hline CHGA & 0 & 1 & 1 & 2 \\
\hline CHMP1A & 0 & 0 & 0 & 0 \\
\hline El24 (stroma) & 0 & 0 & 0 & 0 \\
\hline El24 (tumor) & 0 & 0 & 0 & 0 \\
\hline ENO2 & 0 & 0 & 1 & 1 \\
\hline GADD45B & 0 & 0 & 0 & 0 \\
\hline HA (stroma) & 1 & 1 & 1 & 3 \\
\hline HAS2 & 0 & 0 & 0 & 0 \\
\hline HES6 & 0 & 0 & 0 & 0 \\
\hline HMMR & 2 & 4 & 6 & 6 \\
\hline HOXC6 & 0 & 0 & 0 & 0 \\
\hline HYAL1 & 0 & 0 & 0 & 0 \\
\hline IGF1 & 0 & 0 & 0 & 0 \\
\hline IQCK & 0 & 0 & 0 & 0 \\
\hline MAP4K4 & 0 & 0 & 0 & 0 \\
\hline MKI67 (nuclear) & 0 & 0 & 0 & 0 \\
\hline PAGE4 & 0 & 0 & 0 & 0 \\
\hline PLIN2 & 0 & 0 & 0 & 0 \\
\hline PTEN & 0 & 0 & 0 & 0 \\
\hline SIAH2 (nuclear) & 7 & 10 & 10 & 10 \\
\hline SMAD4 & 4 & 7 & 7 & 8 \\
\hline SOX9 & 0 & 0 & 0 & 0 \\
\hline SPP1 & 0 & 0 & 0 & 0 \\
\hline SYP & 0 & 0 & 0 & 0 \\
\hline TP53_Lab1 (nuclear) & 0 & 0 & 0 & 0 \\
\hline TP53_Lab2 (nuclear) & 0 & 0 & 0 & 0 \\
\hline
\end{tabular}

MVD, microvessel density. cell carcinoma in which HOXC6 directly increases the promoter activity causing overexpression of Bcl-2 [43]. Similarly, HOXC6 represses the activity of pro-apoptotic genes neutral endopeptidase (NEP) and insulin-like growth factor binding protein 3 (IGFBP3) in PCa [41]. Although androgen receptor was not directly investigated in this study, we identified an association between elevated HOXC6 and BF in our cohort which along with these studies provides rationale for further investigation of HOXC6 in the PCa androgen receptor axis.

MAP4K4 is also a pro-migratory protein involved in mammalian development and increases tumor cell motility likely through c-Jun N-terminal kinase (JNK) [44]. Our findings indicated that increased MAP4K4 was significantly associated with time to BF. MAP4K4 is similarly incorporated in numerous independent gene expression signatures which are predictive of survival in colorectal cancer [45] and recurrence in prostate cancer $[16,17]$. Additionally, MAP4K4 is an independent prognostic factor for hepatocellular carcinoma and lung adenocarcinoma $[46,47]$. Xenograft tumor growth in mice using a hepatocellular cell line is substantially inhibited by RNA interference of MAP4K4 [46], indicating a potential therapeutic target that may be useful for treatment of $\mathrm{PCa}$.

Higher protein levels of IGF1 were associated with time to BF in our PCa cohort. This observation was discordant from our initial cross-study analysis of independent gene expression datasets identifying downregulated IGF1 as part of an 11-gene signature of PCa aggressiveness (Additional file 12: Table S11). One recent study shows evidence for decreased IGF1 mRNA in local PCa compared to benign prostate, although IGF1 may still be involved in subsequent tumor progression as this study did not evaluate advanced or metastatic disease [48]. In contrast, our immunohistochemical findings correlate with most literature on the role of increased IGF1 in cancer progression. In androgen-independent PCa, IGF1 induces tumor cell motility by activation of $\alpha v \beta 3$ integrin via the PI3-K/Akt pathway [49]. IGF1 signaling through PI3-K/Akt and $\beta 1$ integrin similarly promotes adhesion and migration in multiple myeloma cells [50].

The PI3-K pathway is also upregulated in transgenic mice expressing tissue-specific IGF1 in prostate basal epithelial cells which leads to constitutive activation of IGF1R and increased development of PCa [51]. Importantly, meta-analysis of large datasets demonstrates an association between high serum IGF1 levels and moderately increased risk of $\mathrm{PCa}$ which may provide an important modifiable target in PCa patients [52].

In addition to IGF1, bioinformatic analysis identifies SMAD4 as a candidate gene likely to be a primary driver of PCa progression [53]. Reports of SMAD4 expression in prostate and other cancers are complex and variable, 
Table 5 Area under the ROC curve (AUC) for 3-year and 5-year recurrence using a 3-biomarker model comprised of HMMR, SIAH2 (nuclear), and SMAD4

\begin{tabular}{lcccc}
\hline & \multicolumn{2}{c}{ 3-year recurrence } & \multicolumn{2}{c}{ 5-year recurrence } \\
\cline { 2 - 5 } & AUC (95\% Cl) & P-value & AUC (95\% Cl) & P-value \\
\hline Unadjusted AUC & $0.708(0.581-0.882)$ & 0.004 & $0.721(0.592-0.880)$ & 0.002 \\
Cross-validation adjusted AUC & $0.685(0.499-0.871)$ & 0.052 & $0.702(0.533-0.866)$ & 0.024 \\
\hline
\end{tabular}

although mutation of the SMAD4 gene appears rare during PCa progression [54]. In normal cells, SMAD4 is a critical component of the TGF- $\beta$ signaling cascade and localizes to the nucleus after becoming activated to regulate TGF- $\beta$-responsive genes and inhibit cellular proliferation [55]. In this sense, SMAD4 may act as a tumor suppressor, which has been demonstrated by reduced expression of SMAD4 in PCa compared to BPH and normal prostate tissue [56]. Interestingly, in our cross-study analysis of gene expression datasets SMAD4 was present in the top 46 ranked genes (position 21) and inversely correlated with $\mathrm{PCa}$ aggressiveness (Additional file 4: Table S3). While Smad-dependent TGF- $\beta$ signaling primarily functions to inhibit growth, the vast majority of tumors acquire resistance to these effects and tumor progression becomes stimulated by TGF- $\beta$ in more advanced tumors [55]. Previous studies have linked increased SMAD4 to higher grade, stage, and DNA ploidy in PCa [57] and to infiltration of the myometrial wall in endometrioid endometrial cancer [58], which is consistent with our immunohistochemical analysis that elevated SMAD4 was significantly associated with time to BF. Similarly, SMAD4 shifts from its tumor suppressor role to an aggressiveness factor in a mouse model of breast cancer by promoting bone metastasis through TGF- $\beta$ activated expression of IL-11 [59]. Advanced primary prostate tumors often metastasize to the bone, potentially reflecting parallel events whereby bone-derived TGF- $\beta$ offers an advantage to SMAD4-overexpressing prostate tumor cells and providing a possible therapeutic target in the TGF- $\beta$ pathway.

HMMR, SMAD4, and SIAH2 comprised a multibiomarker signature that was predictive of $\mathrm{BF}$ in our cohort. SIAH2 is a RING finger ubiquitin ligase which controls the stability of multiple substrates, and under hypoxic conditions, causes ubiquitination/degradation of prolyl hydroxylase 3 and 1 [60]. This action increases the accumulation rate of HIF- $1 \alpha$ and interacts with neuroendocrine-specific expression of FoxA2 leading to neuroendocrine PCa development and metastasis [14,60]. SIAH2 also contributes to castration-resistant $\mathrm{PCa}$ by targeting a subset of inactive androgen receptors for ubiquitination which increases the activity of androgen receptor target genes implicated in PCa progression [61]. Our results which identify SIAH2 in the multibiomarker signature predictive of BF are consistent with these studies and support a functional role for SIAH2 in contributing to aggressive subtypes of PCa.

This study and its conclusions are limited by a small sample size and short follow-up for some individuals. We collected data on 160 patients of which half were followed for less than 2.3 years. As a result, only 22 of the 160 patients in our sample experienced BF even though 67 patients had extraprostatic extension, lymph node involvement, or surgical margin involvement. It is likely that longer follow-up would result in more BF instances. The small number of BF's observed in our sample is directly related to the relatively modest AUC (AUC $\sim 0.7$ for 3- and 5-year BF) observed for our 3biomarker signature. A larger sample size and more events would provide more statistical power for developing a biomarker signature and more precision for evaluating the performance of the new biomarker signature. This retrospective hospital-based cohort study is additionally limited by lack of information regarding (neo)adjuvant therapy. This is an important limitation of our study, since such treatments could potentially affect patient outcomes and thus our interpretations. We plan to complete a larger validation study to further refine our biomarker signature and to obtain more precise estimates of its performance as a classifier for BF.

\section{Conclusions}

This study presents a unique methodology for evaluating the prognostic utility of PCa biomarkers. Because of the precious value of tissues represented in TMAs from large cohorts, we have tested 33 proteins by immunohistochemistry using this cohort of 160 patients in order to identify promising biomarkers for use in significantly larger validation studies [62]. Additionally, this study describes a 3-biomarker signature consisting of HMMR, SIAH2, and SMAD4 proteins which appears to be prognostic in our cohort. This signature may be useful in work currently underway to co-register detailed multibiomarker immunohistochemistry signature maps with multiparametric MR data, for the purpose of identifying MR biomarkers that assess PCa aggressiveness preoperatively in vivo [22]. 


\section{Additional files}

Additional file 1: Development of an $n$-gene signature of prostate cancer aggressiveness by cross-study examination of gene expression profiling data.

Additional file 2: Table S1. Fully normalized RNA expression data (Singh et al.) for the top 1000 most informative genes [500 genes with the most positive $\mathrm{S}_{x}$ (non-aggressive) and 500 genes with the most negative $S_{x}$ (aggressive)] for 21 specimens in the Singh et al. dataset. Genes are ranked by decreasing informational content $\left(\left|S_{x}\right|\right)$.

Additional file 3: Table S2. Fully normalized RNA expression data (Yu et al.) for the top 1000 most informative genes [500 genes with the most positive $S_{x}$ (non-aggressive) and 500 genes with the most negative $S_{x}$ (aggressive)] for 58 specimens in the Yu et al. dataset. Genes are ranked by decreasing informational content $\left(\left|S_{X}\right|\right)$.

Additional file 4: Table S3. Top 46 genes (ranked by |weighted average $S_{x}$ ) with $S_{x}$ values from each dataset. Expression values for genes with multiple probe set ID's were averaged. $S_{x}$ ratios were averaged and weighted to account for difference in sample size between datasets.

Additional file 5: Table S4. Weighted voting calculations for the top 46 ranked genes using normalized gene expression data from the Singh et al. dataset (Additional file 2: Table S1) and weighted average $S_{x}$ values (derived in Additional file 4: Table S3) using the voting equation: $v=S_{x}$ $\left[G_{x}-B_{x}\right]$.

Additional file 6: Table S5. Weighted voting calculations for the top 46 ranked genes using normalized gene expression data from the Yu et al. dataset (Additional file 2: Table S1) and weighted average $S_{x}$ values (derived in Table S3) using the voting equation: $v=S_{x}\left[G_{x}-B_{x}\right]$.

Additional file 7: Table S6. Aggressiveness predictions of $n$-gene models for each specimen in the Singh et al. dataset. These values result from the summation ( $V$ ) of votes for genes added consecutively to the n-gene model: $V=\Sigma_{x} v_{x}$, where the summation $(V)$ is positive (nonaggressive; blue) or negative (aggressive; red). Statistical results for each $n$-gene model are displayed at the end of each row.

Additional file 8: Table S7. Aggressiveness predictions of $n$-gene models for each specimen in the Yu et al. dataset. These values result from the summation ( $V$ ) of votes for genes added consecutively to the n-gene model: $V=\Sigma_{x} v_{x}$, where the summation ( $V$ ) is positive (nonaggressive; blue) or negative (aggressive; red). Statistical results for each $n$-gene model are displayed at the end of each row.

Additional file 9: Table S8. Fully normalized cDNA expression data (Lapointe et al.) for the ranked set of top 46 genes for the 28 specimens in the Lapointe et al. validation dataset.

Additional file 10: Table S9. Weighted voting calculations for the top 46 ranked genes using normalized gene expression data from the Lapointe et al. validation dataset (Additional file 9: Table 58) and weighted average $S_{x}$ values (derived in Table 53 ) using the voting equation: $v=S_{x}\left[G_{x}-B_{x}\right]$.

Additional file 11: Table S10. Aggressiveness predictions of $n$-gene models for each specimen in the Lapointe et al. validation dataset. These values result from the summation ( $V$ ) of votes for genes added consecutively to the $n$-gene model: $V=\Sigma_{x} v_{x}$, where the summation ( $V$ ) is positive (non-aggressive; blue) or negative (aggressive; red). Statistical results for each $n$-gene model are displayed at the end of each row.

Additional file 12: Table S11. Composition of the final 11-gene model validated in the Lapointe et al. dataset.

Additional file 13: Table S12. Control tissues used in immunohistochemistry assays.

Additional file 14: Figure S1. Representative images of selected control tissues demonstrating optimized immunohistochemistry.

Additional file 15: Table S13. Reproducibility of assay methods given by $\mathrm{N}(\%)$ patients for each combination of missing/observed for two independent runs and the correlation coefficients when data were observed in both runs.

\section{Competing interest}

The authors declare that there are no conflicts of interest regarding the publication of this article.

\section{Authors' contributions}

AER, NKR, SCS, and GJM designed and coordinated the study. JSK and RIV provided statistical analysis. CLF performed immunohistochemical staining. AER, LOM, and JRT performed image and data analysis. JCH participated in study coordination and server administration. AER, NKR, GJM, JBM, EAT, CAW, and SCS helped to draft the manuscript. All authors read and approved the final manuscript.

\section{Acknowledgements}

This work was supported by NIH grants R01-CA119092 (JBM, EAT), R01-CA131013 (GJM), University of Minnesota (UMN) Chairman's Fund Endowed Chair in Cancer Biology (JBM), UMN Biostatistics and BioNet core facilities (supported by P30-CA77598, P50-CA101955, KL2-RR033182, UMN Academic Health Center), Fred Hutchinson/University of Washington Cancer Consortium's Northwest BioTrust core facility (supported by P30-CA015704), UMN Department of Laboratory Medicine and Pathology, and University of Washington Department of Pathology (SCS). The authors thank Dr. Timothy Schacker (supported by NIH grants P01-Al074340, R01-Al093319) for providing computer resources used in this study.

\section{Author details}

${ }^{1}$ Department of Pathology, University of Washington, Mailcode 359791, 908 Jefferson St, Seattle, WA 98104, USA. ²Department of Laboratory Medicine and Pathology and Masonic Cancer Center, University of Minnesota, Minneapolis, MN, USA. ${ }^{3}$ Biostatistics and Bioinformatics Core, Masonic Cancer Center, University of Minnesota, Minneapolis, MN, USA. ${ }^{4}$ Division of Biostatistics, School of Public Health, University of Minnesota, Minneapolis, MN, USA. ${ }^{5}$ Department of Radiology, University of Minnesota, Minneapolis, MN, USA. ${ }^{6}$ BioNet, Academic Health Center, University of Minnesota, Minneapolis, MN, USA. 'Department of Biochemistry, London Health Sciences Center, University of Western Ontario, London, Ontario, Canada. ${ }^{8}$ Department of Oncology, London Health Sciences Center, University of Western Ontario, London, Ontario, Canada. ${ }^{9}$ Department of Urology, University of Minnesota, Minneapolis, MN, USA

Received: 13 December 2013 Accepted: 2 April 2014

Published: 5 April 2014

\section{References}

1. Siegel R, Naishadham D, Jemal A: Cancer statistics, 2013. CA Cancer J Clin 2013, 63(1):11-30.

2. Cookson MS, Aus G, Burnett AL, Canby-Hagino ED, D'Amico AV, Dmochowski RR, Eton DT, Forman JD, Goldenberg SL, Hernandez J, Higano CS, Kraus SR, Moul JW, Tangen C, Thrasher JB, Thompson I: Variation in the definition of biochemical recurrence in patients treated for localized prostate cancer: the American Urological Association Prostate Guidelines for Localized Prostate Cancer Update Panel report and recommendations for a standard in the reporting of surgical outcomes. J Urol 2007, 177(2):540-545.

3. Frazier HA, Robertson JE, Humphrey PA, Paulson DF: Is prostate specific antigen of clinical importance in evaluating outcome after radical prostatectomy. J Urol 1993, 149(3):516-518.

4. Pound CR, Partin AW, Eisenberger MA, Chan DW, Pearson JD, Walsh PC: Natural history of progression after PSA elevation following radical prostatectomy. JAMA 1999, 281(17):1591-1597.

5. Han M, Partin AW, Pound CR, Epstein Jl, Walsh PC: Long-term biochemical disease-free and cancer-specific survival following anatomic radical retropubic prostatectomy. The 15-year Johns Hopkins experience. Urol Clin 2001, 28(3):555-565

6. Bismar TA, Demichelis F, Riva A, Kim R, Varambally S, He L, Kutok J, Aster JC, Tang J, Kuefer R, Hofer MD, Febbo PG, Chinnaiyan AM, Rubin MA: Defining aggressive prostate cancer using a 12-gene model. Neoplasia 2006, 8(1):59-68.

7. Ding Z, Wu CJ, Chu GC, Xiao Y, Ho D, Zhang J, Perry SR, Labrot ES, Wu X, Lis R, Hoshida Y, Hiller D, Hu B, Jiang S, Zheng H, Stegh AH, Scott KL, Signoretti S, Bardeesy N, Wang YA, Hill DE, Golub TR, Stampfer MJ, Wong WH, Loda M, Mucci L, Chin L, DePinho RA: SMAD4-dependent barrier constrains prostate cancer growth and metastatic progression. Nature 2011, 470(7333):269-273. 
8. Ekici S, Cerwinka WH, Duncan R, Gomez P, Civantos F, Soloway MS, Lokeshwar VB: Comparison of the prognostic potential of hyaluronic acid hyaluronidase (HYAL-1), CD44v6 and microvessel density for prostate cancer. Int J Cancer 2004, 112(1):121-129.

9. Glinsky GV, Berezovska O, Glinskii AB: Microarray analysis identifies a death-from-cancer signature predicting therapy failure in patients with multiple types of cancer. J Clin Invest 2005, 115(6):1503-1521

10. Glinsky GV, Glinskii AB, Stephenson AJ, Hoffman RM, Gerald WL: Gene expression profiling predicts clinical outcome of prostate cancer. J Clin Invest 2004, 113(6):913-923.

11. Iczkowski KA: Cell adhesion molecule CD44: its functional roles in prostate cancer. Am J Trans/ Res 2010, 3(1):1-7.

12. Korkes F, Castro MG, Zequi SD, Nardi L, Giglio LA, Peo AC: RHAMM immunohistochemical expression and androgen deprivation in normal peritumoural, hyperplasic and neoplastic prostate tissue. BJU international 2013. doi:10.1111/bju.12339. [Epub ahead of print].

13. Lapointe J, Li C, Higgins JP, van de Rijn M, Bair E, Montgomery K, Ferrari M, Egevad L, Rayford W, Bergerheim U, Ekman P, DeMarzo AM, Tibshirani R, Botstein D, Brown PO, Brooks JD, Pollack JR: Gene expression profiling identifies clinically relevant subtypes of prostate cancer. Proc Natl Acad Sci U S A 2004, 101(3):811-816.

14. Qi J, Nakayama K, Cardiff RD, Borowsky AD, Kaul K, Williams R, Krajewski S, Mercola D, Carpenter PM, Bowtell D, Ronai ZA: Siah2-dependent concerted activity of HIF and FoxA2 regulates formation of neuroendocrine phenotype and neuroendocrine prostate tumors. Cancer cell 2010, 18(1):23-38.

15. Singh D, Febbo PG, Ross K, Jackson DG, Manola J, Ladd C, Tamayo P, Renshaw AA, D'Amico AV, Richie JP, Lander ES, Loda M, Kantoff PW, Golub TR, Sellers WR: Gene expression correlates of clinical prostate cancer behavior. Cancer cell 2002, 1(2):203-209.

16. Stephenson AJ, Smith A, Kattan MW, Satagopan J, Reuter VE, Scardino PT, Gerald WL: Integration of gene expression profiling and clinical variables to predict prostate carcinoma recurrence after radical prostatectomy. Cancer 2005, 104(2):290-298.

17. Sun Y, Goodison S: Optimizing molecular signatures for predicting prostate cancer recurrence. Prostate 2009, 69(10):1119-1127.

18. Yu YP, Landsittel D, Jing L, Nelson J, Ren B, Liu L, McDonald C, Thomas R, Dhir R, Finkelstein S, Michalopoulos G, Becich M, Luo JH: Gene expression alterations in prostate cancer predicting tumor aggression and preceding development of malignancy. J Clin Oncol 2004, 22(14):2790-2799.

19. Swanson GP, Basler JW: Prognostic factors for failure after prostatectomy. J Cancer Educ 2010, 2:1-19.

20. Tomlins SA, Rhodes DR, Perner S, Dhanasekaran SM, Mehra R, Sun XW, Varambally S, Cao X, Tchinda J, Kuefer R, Lee C, Montie JE, Shah RB, Pienta KJ, Rubin MA, Chinnaiyan AM: Recurrent fusion of TMPRSS2 and ETS transcription factor genes in prostate cancer. Science 2005, 310(5748):644-648.

21. Shao L, Tekedereli I, Wang J, Yuca E, Tsang S, Sood A, Lopez-Berestein G, Ozpolat B, Ittmann M: Highly specific targeting of the TMPRSS2/ERG fusion gene using liposomal nanovectors. Clin Cancer Res 2012, 18(24):6648-6657.

22. Metzger GJ, Dankbar SC, Henriksen J, Rizzardi AE, Rosener NK, Schmechel SC: Development of multigene expression signature maps at the protein level from digitized immunohistochemistry slides. PloS One 2012, 7(3):e33520.

23. Sagnak L, Topaloglu H, Ozok U, Ersoy H: Prognostic significance of neuroendocrine differentiation in prostate adenocarcinoma. Clin Genitourin Cancer 2011, 9(2):73-80.

24. Bono AV, Celato N, Cova V, Salvadore M, Chinetti S, Novario R: Microvesse density in prostate carcinoma. Prostate Cancer Prostatic Dis 2002, 5(2):123-127.

25. Shurbaji MS, Kalbfleisch JH, Thurmond TS: Immunohistochemical detection of p53 protein as a prognostic indicator in prostate cancer. Hum Pathol 1995, 26(1):106-109.

26. Nanda A, Chen MH, Renshaw AA, D'Amico AV: Gleason Pattern 5 prostate cancer: further stratification of patients with high-risk disease and implications for future randomized trials. Int J Radiat Oncol Biol Phys 2009, 74(5):1419-1423.

27. Sabolch A, Feng FY, Daignault-Newton S, Halverson S, Blas K, Phelps L, Olson KB, Sandler HM, Hamstra DA: Gleason pattern 5 is the greatest risk factor for clinical failure and death from prostate cancer after dose-escalated radiation therapy and hormonal ablation. Int J Radiat Oncol Biol Phys 2011, 81(4):e351-e360.

28. Rizzardi AE, Johnson AT, Vogel RI, Pambuccian SE, Henriksen J, Skubitz AP, Metzger GJ, Schmechel SC: Quantitative comparison of immunohistochemical staining measured by digital image analysis versus pathologist visual scoring. Diagn Pathol 2012, 7:42.

29. Krajewska M, Smith LH, Rong J, Huang X, Hyer ML, Zeps N, lacopetta B, Linke SP, Olson AH, Reed JC, Krajewski S: Image analysis algorithms for immunohistochemical assessment of cell death events and fibrosis in tissue sections. J Histochem Cytochem 2009, 57(7):649-663.

30. Van Buuren S, Brand JPL, Groothuis-Oudshoorn CGM, Rubin DB: Fully conditional specification in multivariate imputation. J Stat Comput Sim 2006, 76(12):1049-1064.

31. van Buuren S, Groothuis-Oudshoorn K: Mice: multivariate Imputation by Chained Equations in R. J Stat Softw 2011, 45(3):1-67.

32. Simon N, Friedman J, Hastie T, Tibshirani R: Regularization Paths for Cox's Proportional Hazards Model via Coordinate Descent. J Stat Softw 2011, 39(5):1-13.

33. Heagerty PJ, Lumley T, Pepe MS: Time-dependent ROC curves for censored survival data and a diagnostic marker. Biometrics 2000, 56(2):337-344.

34. Ali AM, Dawson SJ, Blows FM, Provenzano E, Ellis IO, Baglietto L, Huntsman D, Caldas C, Pharoah PD: Comparison of methods for handling missing data on immunohistochemical markers in survival analysis of breast cancer. $\mathrm{Br} J$ Cancer 2011, 104(4):693-699.

35. Maxwell CA, McCarthy J, Turley E: Cell-surface and mitotic-spindle RHAMM: moonlighting or dual oncogenic functions? J Cell Sci 2008, 121(Pt 7):925-932.

36. Simpson MA, Lokeshwar VB: Hyaluronan and hyaluronidase in genitourinary tumors. Front Biosci 2008, 13:5664-5680.

37. Gust KM, Hofer MD, Perner SR, Kim R, Chinnaiyan AM, Varambally S, Moller P, Rinnab L, Rubin MA, Greiner J, Schmitt M, Kuefer R, Ringhoffer M: RHAMM (CD168) is overexpressed at the protein level and may constitute an immunogenic antigen in advanced prostate cancer disease. Neoplasia 2009, 11(9):956-963.

38. Slevin M, Krupinski J, Gaffney J, Matou S, West D, Delisser H, Savani RC, Kumar S: Hyaluronan-mediated angiogenesis in vascular disease: uncovering RHAMM and CD44 receptor signaling pathways. Matrix Biol 2007, 26(1):58-68.

39. Nedvetzki S, Gonen E, Assayag N, Reich R, Williams RO, Thurmond RL, Huang JF, Neudecker BA, Wang FS, Turley EA, Naor D: RHAMM, a receptor for hyaluronan-mediated motility, compensates for CD44 in inflamed CD44-knockout mice: a different interpretation of redundancy. Proc Nat/ Acad Sci U S A 2004, 101(52):18081-18086

40. Tolg C, Hamilton SR, Zalinska E, McCulloch L, Amin R, Akentieva N, Winnik F, Savani R, Bagli DJ, Luyt LG, Cowman MK, McCarthy JB, Turley EA: A RHAMM mimetic peptide blocks hyaluronan signaling and reduces inflammation and fibrogenesis in excisional skin wounds. Am J Pathol 2012, 181(4):1250-1270.

41. Ramachandran S, Liu P, Young AN, Yin-Goen Q, Lim SD, Laycock N, Amin MB, Carney JK, Marshall FF, Petros JA, Moreno CS: Loss of HOXC6 expression induces apoptosis in prostate cancer cells. Oncogene 2005, 24(1):188-198.

42. McCabe CD, Spyropoulos DD, Martin D, Moreno CS: Genome-wide analysis of the homeobox C6 transcriptional network in prostate cancer. Cancer Res 2008, 68(6):1988-1996.

43. Moon SM, Kim SA, Yoon JH, Ahn SG: HOXC6 is deregulated in human head and neck squamous cell carcinoma and modulates $\mathrm{Bcl}-2$ expression. J Biol Chem 2012, 287(42):35678-35688.

44. Collins CS, Hong J, Sapinoso L, Zhou Y, Liu Z, Micklash K, Schultz PG, Hampton GM: A small interfering RNA screen for modulators of tumor cell motility identifies MAP4K4 as a promigratory kinase. Proc Natl Acad Sci U S A 2006, 103(10):3775-3780.

45. Hao JM, Chen JZ, Sui HM, Si-Ma XQ, Li GQ, Liu C, Li JL, Ding YQ, Li JM: A five-gene signature as a potential predictor of metastasis and survival in colorectal cancer. J Pathol 2010, 220(4):475-489.

46. Liu AW, Cai J, Zhao XL, Jiang TH, He TF, Fu HQ, Zhu MH, Zhang SH: ShRNAtargeted MAP4K4 inhibits hepatocellular carcinoma growth. Clin Cancer Res 2011, 17(4):710-720.

47. Qiu MH, Qian YM, Zhao XL, Wang SM, Feng XJ, Chen XF, Zhang SH: Expression and prognostic significance of MAP4K4 in lung adenocarcinoma. Pathol Res Pract 2012, 208(9):541-548.

48. Massoner $\mathrm{P}$, Ladurner Rennau M, Heidegger I, Kloss-Brandstatter A, Summerer M, Reichhart $\mathrm{E}$, Schafer $\mathrm{G}$, Klocker $\mathrm{H}$ : Expression of the IGF axis is decreased in local prostate cancer but enhanced after benign prostate epithelial differentiation and TGF-beta treatment. Am J Pathol 2011, 179(6):2905-2919. 
49. Montagnani Marelli M, Moretti RM, Procacci P, Motta M, Limonta P: Insulin-like growth factor-I promotes migration in human androgenindependent prostate cancer cells via the alphavbeta3 integrin and PI3-K/Akt signaling. Int J Oncol 2006, 28(3):723-730.

50. Tai YT, Podar K, Catley L, Tseng YH, Akiyama M, Shringarpure R, Burger R, Hideshima T, Chauhan D, Mitsiades N, Richardson P, Munshi NC, Kahn CR, Mitsiades C, Anderson KC: Insulin-like growth factor-1 induces adhesion and migration in human multiple myeloma cells via activation of beta1-integrin and phosphatidylinositol 3'-kinase/AKT signaling. Cancer Res 2003, 63(18):5850-5858.

51. DiGiovanni J, Kiguchi K, Frijhoff A, Wilker E, Bol DK, Beltran L, Moats S, Ramirez A, Jorcano J, Conti C: Deregulated expression of insulin-like growth factor 1 in prostate epithelium leads to neoplasia in transgenic mice. Proc Natl Acad Sci U S A 2000, 97(7):3455-3460.

52. Roddam AW, Allen NE, Appleby P, Key TJ, Ferrucci L, Carter HB, Metter EJ, Chen C, Weiss NS, Fitzpatrick A, Hsing AW, Lacey JV Jr, Helzlsouer K, Rinaldi S, Riboli E, Kaaks R, Janssen JA, Wildhagen MF, Schröder FH, Platz EA, Pollak M, Giovannucci E, Schaefer C, Quesenberry CP Jr, Vogelman JH, Severi G, English DR, Giles GG, Stattin P, Hallmans G, et al: Insulin-like growth factors, their binding proteins, and prostate cancer risk: analysis of individual patient data from 12 prospective studies. Ann Intern Med 2008, 149(7):461-471. W483-468.

53. Gorlov IP, Sircar K, Zhao H, Maity SN, Navone NM, Gorlova OY, Troncoso P, Pettaway CA, Byun JY, Logothetis CJ: Prioritizing genes associated with prostate cancer development. BMC Cancer 2010, 10:599.

54. MacGrogan D, Pegram M, Slamon D, Bookstein R: Comparative mutational analysis of DPC4 (Smad4) in prostatic and colorectal carcinomas. Oncogene 1997, 15(9):1111-1114.

55. Elliott RL, Blobe GC: Role of transforming growth factor Beta in human cancer. J Clin Oncol 2005, 23(9):2078-2093.

56. Horvath LG, Henshall SM, Kench JG, Turner JJ, Golovsky D, Brenner PC, O'Neill GF, Kooner R, Stricker PD, Grygiel JJ, Sutherland RL: Loss of BMP2, Smad8, and Smad4 expression in prostate cancer progression. Prostate 2004, 59(3):234-242

57. Sheehan GM, Kallakury BV, Sheehan CE, Fisher HA, Kaufman RP Jr, Ross JS: Smad4 protein expression correlates with grade, stage, and DNA ploidy in prostatic adenocarcinomas. Hum Pathol 2005, 36(11):1204-1209.

58. Piestrzeniewicz-Ulanska D, Brys M, Semczuk A, Rechberger T, Jakowicki JA, Krajewska WM: TGF-beta signaling is disrupted in endometrioid-type endometrial carcinomas. Gynecol Oncol 2004, 95(1):173-180.

59. Kang Y, He W, Tulley S, Gupta GP, Serganova I, Chen CR, Manova-Todorova K, Blasberg R, Gerald WL, Massague J: Breast cancer bone metastasis mediated by the Smad tumor suppressor pathway. Proc Natl Acad Sci U S A 2005, 102(39):13909-13914.

60. Nakayama K, Frew IJ, Hagensen M, Skals M, Habelhah H, Bhoumik A, Kadoya T, Erdjument-Bromage $H$, Tempst P, Frappell PB, Bowtell DD, Ronai Z: Siah2 regulates stability of prolyl-hydroxylases, controls HIF1alpha abundance, and modulates physiological responses to hypoxia. Cell 2004, 117(7):941-952.

61. Qi J, Tripathi M, Mishra R, Sahgal N, Fazli L, Ettinger S, Placzek WJ, Claps G, Chung LW, Bowtell D, Gleave M, Bhowmick N, Ronai ZA: The E3 ubiquitin ligase Siah2 contributes to castration-resistant prostate cancer by regulation of androgen receptor transcriptional activity. Cancer cell 2013, 23(3):332-346.

62. Koopmeiners JS, Vogel Rl: Early termination of a two-stage study to develop and validate a panel of biomarkers. Stat Med 2013, 32(6):1027-1037.

\section{Submit your next manuscript to BioMed Central and take full advantage of:}

- Convenient online submission

- Thorough peer review

- No space constraints or color figure charges

- Immediate publication on acceptance

- Inclusion in PubMed, CAS, Scopus and Google Scholar

- Research which is freely available for redistribution

Submit your manuscript at www.biomedcentral.com/submit
C Biomed Central 